\title{
Gamification in organizations: learning processes and meaning-making
}

\author{
SORAIA FINAMOR NEIDENBACH ${ }^{1}$ \\ VANESSA MARTINES CEPELLOS ${ }^{1}$ \\ Jussara Jéssica PEREIRA ${ }^{1}$
}

1 Fundação Getulio Vargas (FGV EAESP) / Escola de Administração de EMPresas de São Paulo, SÃo PaUlo - SP, BrazIL

\begin{abstract}
This study presents a view of gamification as a possibility for meaning-making learning. It analyzes the perception of learning processes and meaning-making through gamification when used as an organizational tool. Six gamification experts were interviewed, and thematic analysis was carried out, discussing the data based on two levels, organizational and individual, and three dimensions, organization, team, and worker. The interviewees perceived that gamification produces positive results at organizational and individual levels, suggesting gains in the three dimensions. As for the organizational dimension, the interviewees perceived more productivity, learning, innovation processes, and update of the organization's systems. Concerning the team dimension, there was an improvement in the organizational climate, communication, and collaborative work. Finally, in the individual dimension, the interviewees perceived worker's development, more autonomy, an increase in self-esteem, greater transparency in the relationship between leaders and followers, and empowerment.
\end{abstract}

Keywords: Gamification. Management. Learning. Meaning-Making.

\section{Gamificação nas organizações: processos de aprendizado e construção de sentido}

\section{Resumo}

Este estudo apresenta uma visão dessa gamificação como possibilidade de aprendizado via construção de sentido. Para tanto, adotamos a seguinte pergunta de pesquisa: como são percebidos os processos de aprendizado e a construção de sentido da gamificação como ferramenta organizacional? A partir dos relatos de seis expertises na área e por meio da análise temática, chegou-se a dois níveis de análises: a) o nível organizacional e b) o nível individual. Tais níveis foram apresentados em três dimensões: a organização, o time/a equipe e a individual do trabalhador. Foi identificada a existência de bons resultados para os níveis organizacional e individual. Assim, destaca-se na dimensão organizacional a melhoria na produtividade, na aprendizagem e nos processos de inovação e update organizacional. Na dimensão de time/equipe, notaram-se melhorias no clima organizacional, na comunicação e no trabalho colaborativo. Na dimensão individual, houve desenvolvimento do trabalhador, autonomia, autoestima e maior transparência na relação entre líderes e liderados, bem como empoderamento.

Palavras-chave: Gamificação. Gestão. Aprendizado. Construção de Sentido.

\section{Gamificación en organizaciones: procesos de aprendizaje y creación de significado}

\section{Resumen}

Este estudio presenta una visión de la gamificación como una posibilidad de aprendizaje mediante la creación de significado. Para ello, adoptamos la siguiente pregunta de investigación: ¿Cómo se perciben los procesos de aprendizaje y la creación de significado de la gamificación como herramienta organizativa? De los informes de seis expertos en el área y, a través del análisis temático, llegamos a dos niveles de análisis: a) El nivel organizacional y b) El nivel individual. Dichos niveles de análisis se presentaron a través de tres dimensiones: la organización, el equipo y la dimensión individual del trabajador. Identificamos la existencia de buenos resultados para los niveles organizacional e individual. Así, se destacan en la dimensión organizacional, la mejora en la productividad, en el aprendizaje y en los procesos de innovación y actualización organizacional. En la dimensión del equipo, hubo mejoras en el clima organizacional, en la comunicación y en el trabajo colaborativo. En la dimensión individual, se observó desarrollo del trabajador, autonomía, autoestima y mayor transparencia en la relación entre líderes y seguidores, así como el empoderamiento.

Palabras clave: Gamificación. Gestión. Aprendizaje. Construcción de sentido. 


\section{INTRODUCTION}

In this article gamification is understood as a learning strategy (CAILLOIS, 2017) which becomes possible considering the several socio-anthropological changes related to the way of living, but mainly with the headway made by the teaching-learning technologies and by the ludic culture (BROUGÈRE, 1998). The area of study of gamification includes games, toys, jokes and playfulness, and it also interfaces with other themes, such as fantasy, imagination, idleness and leisure (FORTUNA, 2017). The theme's scope beckons to several possibilities of intersection, but in this article the tool applied to the management context is specifically analyzed.

Videogames and the virtual environment have been studied from different perspectives. Among them those which use gamification to improve the way companies engage clients and employees (ROBSON, PLANGGER, KIETZMANN et al., 2016), as strategy to enhance risk management in a business (BAJDOR and DRAGOLEA, 2011), in corporate innovation processes (SHPAKOVA, DÖRFLER and MACBRYDE, 2020), as a teaching-learning tool in management based on the Classcraft platform (SANCHEZ, YOUNG and JOUNEAU-SION, 2017), and even in order to make healthcare interventions in disease control (THENG, LEE, PATINADAN et al., 2015).

The literature on games and management is mostly directed toward improving processes and performances by using a previous experience through gamification. That is so because one of its major advantages is to forecast potential situations and conflicts and their resolution before they occur in the real world. Understood as a tool to design behaviors, develop skills and, consequently, enable innovation processes, gamification, when combined with other technologies, is able to improve employees' performance, learning and to develop client engagement (BURKE, 2012). The pertinence of and interest in gamification applied to the management context have been increasing due to the use of corporate simulation methodologies, such as project-based learning (PBL). Those simulations are able to stimulate qualification of professionals with self-questioning capacity and to have them develop systemic thinking (VERSIANI and FACHIN, 2007). Additionally, they are a teaching strategy through which learners have the opportunity of solving problems, making decision and doing complex and challenging tasks, with positive impacts on learning processes and outcomes (GÓMEZ-PABLOS and MUÑOZ-REPISO, 2019). Gradually, those concepts have been providing support to new pedagogies and didactics in organizations.

For Caillois (2017), the word "game" suggests the idea of useful freedom, which makes mobility an indispensable requirement. Thus, the game subsists among several mechanisms which enable efficacious operation of a structure. Within the context of the organizations, that games' useful freedom is determined by its pedagogical and ludic nature once they contribute to employees' learning and to good organizational operation. Although the presence and contribution of studies on learning in corporate simulations, (VERSIANI and FACHIN, 2007) and in game and education (BROUGÈRE, 1998, 2002) can be observed, a gap still remains when we consider gamification as a teaching and learning tool.

Therefore, this article contributes to the management field by understanding gamification as a teaching-learning strategy, as sensemaking and accumulation of previous experiences. For those purposes, the research question was: how are the teaching-learning processes and the sensemaking perceived in the implementation of gamification as an organization tool? As general and specific objectives it was sought: I) to analyze the impacts perceived, at organizational and individual levels, when gamification was implemented; II) to describe learning criteria in the intersections among the dimensions related to the organization, to the team/group and to the individual. In order to understand the nuclear question six experts in the area were interviewed. The data obtained were submitted to "thematic analysis".

Gamification, as much as corporate training games, encompasses mechanisms to solve problems of management, operational efficiency and increased corporate productivity (DEWINTER, KOCUREK and NICHOLS, 2014). That assumption can explain managers and researchers' increasing interest in thinking business practices in an innovative, attractive and engaging way (ROBSON, PLANGGER, KIETZMANN et al., 2015). Gamification corresponds to the use of games' mechanisms for the purposes of solving practical problems or to trigger engagement of a specific audience, and mainly to speed up learning or training processes thus making tedious or repetitive tasks more agreeable (VIANNA, VIANNA, MEDINA et al., 2014). 
Due to an increase in the possibilities of access to information, regardless of the device people use or the place they are at, they have opportunity to learn and study anytime and anywhere because the mobile technologies they use daily are more and more cloud based (JOHNSON, ADAMS and HAYWOOD, 2011). In this sense, the technology has changed the way the corporate world connects and organizes itself, by structuring new models, spaces and projects. The digital model enabled by gamification goes beyond face-to-face interactions, breaking the traditional patterns of time, distance, cost and connectivity.

In addition to this introduction, this article presents the theoretical framework explored and definitions of gamification, gamification implementation and the outcomes expected. Next, the methodological procedures are presented, followed with analysis and discussion of the findings and, lastly, the final considerations.

\section{THEORETICAL FRAMEWORK}

\section{Gamification \& learning}

Technology, mobile devices, social networks and the whole logic based on the World Wide Web (WEB) have significantly changed the way workers and organizations relate to each other. As to leaning, that change has accompanied the increasing technological advances of an information-based economy (BELTRÃO and BARÇANTE, 2019). This scenario where organizations have been performing for the last decades is called the knowledge era (CASTELLS, 1999) and it is characterized by a deep transformation in the access to knowledge and its production through the Internet. Thus, in contemporary organizations, to learn, relearn, unlearn, adapt, innovate and change, analyze, imitate, renew, automatize and technologize have become the main components of any organizational effort (NOGUEIRA and ODELIUS, 2015).

Recent researches have shown that as to learning, organizations have to understand not only the way how the learning process occurs, but mainly the aspects influencing the knowledge (ODELIUS, ABBAD, RESENDE JUNIOR et al., 2011). By understanding the game and its ludic characteristic in the process of knowledge production (D'ÁVILA, 2014; LUCKESI, 2005), this article explores the intersections between learning and gamification in organizations.

The first references to games came up in the 1980s, with Richard Bartle, through the English word gamifying, which means: "To transform non-game something into game". The first use of the word gamification occurred in 2003 by the British developer Nick Pelling and then it laid dormant until game researchers came up with it in the middle of discussions about videogame's potential benefits (WERBACH and HUNTER, 2012). Alves (2015) defines gamification as "game thinking", which consists of transforming a daily activity into an activity containing the game elements, such as competition, cooperation, exploration, awarding, storytelling, among them.

Game is an important social fact of contemporary culture once it consists of manipulating images representing a certain reality (HUIZINGA, 1971). Additionally, it allows valuating several learning dimensions through its ludic effect (BROUGÈRE, 2002). The idea of organizational learning points at taking advantage of positive emotional energies arising from "action learning" (GARRATT, 1999; REVANS, 1982). For Argyris and Schön (1978), said learning occurs when individuals of the organization experience a problem situation and start to investigate it. When those individuals experience some incompatibility among the results expected and the actual results obtained from that action, they respond through a thinking process that leads to having them change the images they have of the organization and their understanding of the organizational phenomena. These events lead individuals to restructure their activities to match the objectives expected, thus changing the organizational process being used at that time (WANG and AHMED, 2003).

Within this scenario, gamification starts to represent mechanisms and tools able to preset tangible alternatives to deal with learning and to suggest a new way of seeing work relations (VIANNA, VIANNA, MEDINA et al., 2014). Gamification activates the issue of individuality inserted in the game system by taking into account peoples' feelings, their insecurities and the reasons why they want, or do not want, to do something, and then it optimizes those feeling, motivations and it stimulates 
engagement (CHOU, 2013). Consequently, gamification has become more and more popular in different environments by showing positive results as to motivating teams in private organizations (VENTRICE, 2009).

Different from other techniques used in the human resources area, gamification stimulates and triggers feelings of conquest (MARRAS and TOSE, 2012) - for instance, aspects linked to performance evaluation can be observed after the tool has been implemented. In this sense, participants' headway is based on clear and objective criteria, thus promoting ways to evaluate performance without the "weight" of the conventional processes, most of which are currently applied on specific dates, thus creating anxiety, stress and insecurity in the employees assessed.

Gamification is the task of taking elements of fun and engagement from conventional games and applying them to production activities (CHOU, 2013). It consists of using the design of digital experiences in games to motivate and engage people in reaching goals (BURKE, 2015; GARTNER, 2011). The strategy's definition also includes: 1) games' mechanics and their key elements as leaderboards, badges and points (LBP); 2) design of digital experience represented by the path players will have to go through, such as game description, step-by-step procedures, environment recognition and script decoding; 3 ) methods to engage individuals virtually with computers, tablets, smartphones and other digital devices; and 4) people's motivation and pro-technology behavior referring to the use technologies, stimulation of innovation and development of skills. proactive use of technologies, stimulus to innovation and development of skills. Burke (2015) states that gamification increases both players and organizations' potential for reaching goals.

By using games workers are challenged to have certain preset behavior to be granted an award that makes sense to them. It is necessary to do a motivational work with employees which results in engagement with the goal set and mutual benefit for them and for the company. Other advantage refers to the gamification's scope, once it can contribute to socialization of information, allowing to reach different generations and to overcome physical delimitation (BURKE, 2015). The tool and its potential for organizational learning depend on games' implementation and design, as demonstrated hereinafter.

\section{Implementation of gamification}

According to Alves (2015, p. 27), a gamification system able to stimulate engagement should be designed similarly to an "abstract challenge, defined with clear rules, interacting and accepting feedback, with quantifiable results being reached and with the presence of emotional reactions". Said design needs to take into account, first of all, whether gamification is the answer to the problems faced by the organization. Often enough people are more "infatuated" with a trend than with finding efficient solutions for their problems (BURKE, 2015). In order to avoid that mistake, the first step for building up a gamified design is to analyze the company's objectives.

To assess whether gamification is indeed the tool able to help the organization it is necessary to heed some aspects of the planning project. To define the target audience, i.e., who the method design is supposed to reach. To define players' objectives aligned with the company's objective, which were set at the beginning of the planning project. To determine players' engagement model - it is important to use social elements and that the design promotes cooperation more than competition. To define the game environment and the path to be taken, their actions and their engagement cycles. To define incentives and rewards and, finally, to test and repeat the game once "the gamified design of the experience should build up solutions from bottom to top (BURKE, 2015, p. 84). Therefore, a continuous connection between the project and the players' reality is necessary (SANTINHO, 2018). This is important because the joke may trigger emotions, languages and conversations (MATURANA and VERDEN-ZÖLLER, 2004) directly related to the group, individual and organizational learning. Gamification design cannot be limited to the tools' technicity to be used or to the game's elements, it will have to offer a path integrated to people's needs, and with technological possibilities and requirements for a successful experience (BURKE, 2015; SANTINHO, 2018).

The success of gamification simultaneously depends of consistence and alignment of the aspects involved in the game, such as emotions, dynamics and rewards (ROBSON, PLANGGER, KIETZMANN et al., 2016). Engagement techniques are also implemented, and they help both a successful implementation of the games and the ludic aspect. Thus, professional development becomes a moment of fun, joyful and productive. It takes human beings to their childhood and explore a deep connection between loving and playing (MATURANA and VERDEN-ZÖLLER, 2004). 
Gamification is a method to engage individuals digitally instead of personally (BURKE, 2015). Its objective is to motivate people to change their behaviors, to develop skills or to stimulate innovation. Its use mirrors the organization's initiative of searching for qualification and reaching its goals in an attractive way, in order to stimulate the behaviors required to reaching objectives and to broaden the development of their businesses. The gamification's objectives will reach higher levels of engagement that will change behaviors and stimulate innovation (GARTNER, 2011).

Next, the aspect referring to the methods used in this research will be described.

\section{METHODOLOGICAL PROCEDURES}

With a qualitative and exploratory nature, this study conducted six semi-structured interviews with gamification consultants who had already implemented the tool in the retail area. The interviews lasted 1 hour and a half on average and were conducted in two ways: in person and via Skype. The audios collected were transcribed for further analysis. The participants' identity was protected by using names E1, E2, etc. when quoting the interviewees, as shows Box 1, where the research subjects are presented.

Box 1

Research subjects

\begin{tabular}{|c|c|c|}
\hline Interviewees & Position & Scenario where the tool was used \\
\hline E1 & Consultant, Senior & Performance management \\
\hline E2 & Human resources manager & $\begin{array}{c}\text { Management of performance and } \\
\text { organizational }\end{array}$ \\
\hline E3 & Director & $\begin{array}{c}\text { Management of performance, } \\
\text { organizational climate and learning tool }\end{array}$ \\
\hline E4 & Technology \& Development Analyst, Senior & Learning (training) tool \\
\hline E5 & Product \& Bl Executive Manager & Learning (training) tool \\
\hline E6 & Performance management \\
\hline
\end{tabular}

Source: Elaborated by authors.

The context of this research is related to the presence of gamification in organizations. The interviewees selected were responsible for leading the implementation and for following up the tool in retail organizations. The retailers interviewed who had implemented gamification as a learning strategy consider it an innovative and stimulating content learning (training) solution that enables scale gains and is less expensive to implement.

Data were collected by the first author, who was also in charge of making the initial contact and selecting subjects. During data collection two scenarios came up, the first one related to performance management of a team, and the second as an organizational and individual learning solution. As to the questions, they totaled fifteen (15), and they would be asked accordingly to what the research subjects considered important. The semi-structured script was previously sent to the subjects together with a document of informed consent. With the data collected and transcribed, the method of thematic analysis was chosen for the purposes of understanding, describing and interpreting them.

The whole material analyzed resulted from the interviews conducted. The thematic analysis is a process of identifying patterns and themes with data obtained in a qualitative research. This method's objective is to identify themes, i.e., patterns in the data which are relevant for the research objectives and, based on them, to understand aspects of the object studied. It is done accordingly to six fundamental phases.

The first phase targets on getting researcher acquainted with the data. It consists of reading and rereading the transcriptions it is important that the researcher is familiar with the whole corpus of data. The second phase consists of the first codification of the material transcribed for the purposes of organizing the data systemically, which allows organizing a significant volume of data in small groups of senses. The third phase encompasses a search for themes, being considered as such the pattern that 
captures something meaningful of interesting about a datum or a research question. The codes of the previous phase can be grouped in broad themes aligned with specific questions. In the fourth phase the thematic codes pointed out in the second phase are revised. That is when it is checked whether the codification done is consistent with the general plan of the data collected and of the research as a whole. The themes have to be consistent and different from each other. The fifth phase proposes refining in order to identify the thematic essence, showing the need of understanding what each theme is saying, whether there are sub-themes and how to integrate them, and how they relate to each other. At last, the sixth step is writing down the findings. Next, the data and the discussions are presented (MAGUIRE and DELAHUNT, 2017).

On the triangulation of the analyses, after a first round of analysis made by the first author, researchers got together to discuss the findings. Through an interactive process, the second and third authors also analyzed the material from the interviews separately and submitted their analyses. All researchers' results were compared, the communalities and patterns were observed, and plausibility of the interpretations was guaranteed. Three thematic dimensions were verified when the data were analyzed.

On the drawing of the analyses and their reliability, based on an interactive research process, there was a circular path among the data and concepts presented in the theoretical framework (MERRIAM, 2002; STRAUSS and CORBIN, 1998).

\section{DATA ANALYSIS}

Based on the thematic analysis, two level of analyses were reached. They are: a) at organizational level and b) at individual level or corporative perspective; and b) from individuals or workers' perspective. Those, on their turn, do not exclude each other, they complement each other, although the intermediate dimension (team/group) is the one with more contact with the other two.

In the thematic analysis, codification is done in an open way. Thus, one can realize that the research subjects would talk about learning via gamification in two aspects: 1) based on an organizational or corporate perspective; and 2) based on the individual or worker's perspective. Next, data were separated into two large sets: "organization" and "individual", which constitute two levels of analysis, once they present different elements. For instance, the research subjects, when reporting the main changes after gamification tended to separate the two dimensions: "in the organization an increase/decrease in ' $X$ ' was observed" and in the "employees a change in behavior ' $Y$ ' was observed". On the other hand, gamification's benefits were perceived both in the "organization" and "individual" sets and in its intersection with "team/group", these named dimensions, as already mentioned here.

Next, each theme proposed is detailed.

\section{Organizational dimension}

Understanding gamification as an organization's ally, interviewees stressed the use of the tool as a dynamic, innovative and stimulating solution to trigger employees' interest (VENTRICE, 2009). They recognized that the game per se needs to be worked jointly with other management elements for the experience to be rich and valid both for employees and for the company. Thus, employees have an opportunity to develop themselves, its being a training tool less expensive for the company once the gamified process means smaller investment related to training courses to be attended in person.

It is not only a technical game to change the system which would ease the process within the store. In addition to the part of the process for continuous improvement within the activity, there was also the whole work oriented toward strengthening values and creating engagement [E4].

Based on this speech it was possible to observe the existence of two levels of analysis, the organization and the individual levels in the perception of the gamification. It can be observed in the word "store", which points at something more structural, and "work", which implies something more individual. Moreover, when those two levels related to each other, they can be explained based on three dimensions: organization, team/group and worker. When the interviewee says that "there was (...) a whole work oriented toward strengthening values and creating engagement", it can be interpreted that the change related to the gamification process requires integration, communication and co-creation among organization, workers and their team. 
About the organizational dimension, the analysis of the interviewees' speeches shows that what motivates the attempt to use that tool is related to the innovation and to an update of the organization systems, and to engagement, motivation, stimulus and development of skills necessary to the company's daily life (BURKE, 2015).

The system was old and obsolete....we had to develop a gamified learning platform which encompassed the 10 thousand employees; out of those, 9 thousand employees work in stores and approximately 800 employees work in internal services, which is the parent company [E4].

In this speech, for instance, the word "system" leads to an interpretation of elements bound more to the structure of the organizational level than to that of the individual level. Thus, implementing gamification as an organizational learning tool was in consonance with researches that demonstrate that games are well regarded by researchers in education (DOMÍNGUEZ, SAENZ-DE-NAVARRETE, DE-MARCOS et al., 2013) because it configures entertainment that involve people in interactive activities within an active learning process (KOSTER, 2013). Moreover, games can promote a fictional context in the shape of narratives, graphic images and music, encouraging players in other non-game topics (WATSON, MONG and HARRIS, 2011).

Let's think of a game, let's do it online, because we would gain as to finance and speed; and also, once we're going in this rhythm, let's modernize, let's modernize the ways of learning, because nowadays several companies are using gamification. And that was why we chose it [E4].

Interviewees stressed the importance of the gamification tool for an organization with more than 23 thousand employees because, in addition to easing learning, they realized that the tool would bring benefits able to stimulate productivity. However, the corporate strategy should be aligned with constant search for innovation, i.e., as a way to speed up the learning processes (VIANNA, VIANNA, MEDINA et al., 2014).

The gamification issue was a plus, new clothes, the cherry on the icing of the cake (...). We are also using the gamification technique without using the platform, as a methodology to create a ranking in order to increase productivity among employees [E5].

Under this perspective, Burke (2015) points out the existence of many advantages in the use of a digital model, such as: scale and distance, once this type of interaction can connect audiences of any sizes and at any places; time, once they do not depend on other people to be available in real time; and cost, once digital interaction cost much less than those in person.

The first time we received a comment of our ombudsman was, do you know what? "Mister $\mathrm{X}$ is amazing because he asks me every day how I'm feeling". He [the employee] felt he was seen. Under the gamification's point of view, [it was] what brought him here inside [E3].

Gamification offers a way of motivation where personal contact is substituted by a model of digital involvement (BURKE, 2015). Under the point of view of promotion of feelings of belonging and transparency to employees, the platforms of digital games can favor that perception without necessarily doing it in employees' real time, but in the time made available by the platform.

\section{Group or team dimension}

Understanding gamification as an ally simultaneously of the organization and the employee, related to the group/team dimension, it is worth stressing that its process can help organizing groups by identifying strengths and weaknesses and combining those elements in a balanced team or group (ZICHERMANN and CUNNINGHAM, 2011). Still, it can be characterized as a process to create symmetry among the skills of the individuals composing the team. According to the interviews, the main indications for using gamification are due to two scenarios: management of the team's performance and as a corporate learning solution (SANTINHO, 2018). Climate management aligned to performance was also pointed out by the consultants interviewed. In this sense, one of the main factors justifying the whole interest triggered by the games is related to the perception of its 
attractivity, also mirrored on the capacity of creating engagement and dedication within the corporate context (VIANNA, VIANNA, MEDINA et al., 2014).

My client said: "we need to face this new commissioning model and make it more fun, and to link performance to commission, to make it more fun, binding performance with commission, etc. (...) to renovate the culture" [E1].

It can be observed that the process of designing the gamification tool in the organizations interviewed had started in meetings among consultants, high administration and other areas involved, in order to define and align the team's expectations of the tool. Once the "design of a gamified experience should build up solutions from bottom to top" (BURKE, 2015, p. 84), most of the interviewees highlighted the importance of consulting all areas involved in that phase of elaboration. They used the intranet, e-mail marketing and sensitizing speeches which would highlight the importance of having everybody participate for the tool to succeed.

Collaboration and teamwork are elements constantly used in games. Thus, the professionals who made suggestions more often can be recognized by digital platforms oriented towards the purpose of not only to track activities, but also to point at new opportunities of contribution, by promoting intrinsic motivation based on public recognition. The idea of making initiatives tangible, or even to allow they take more ludic outlines (HUIZINGA, 1971) by means of elements coming from games may come to awake positive competitivity, thus generating spontaneous commitment to performing tasks that do not stimulate the mind (VIANNA, VIANNA, MEDINA et al., 2014).

Gamification was stimulated not to create competition among people, but to stimulate collaboration among people. Collaborating is cool and collaboration is worth points [E3].

The games guidelines contributed to establish certain points - for instance, the aspect of cooperation among players (ALVES, 2015). After a clear definition of the problem to be solved, of the context involved, of the understanding of the business objective, of the players' profiles and of the mission determined, the format of the game was defined, being composed of: theme, story and aesthetics. On the other hand, the gamification tool was acquired to stimulate employees' learning and engagement. Their involvement, their motivation and a decrease in turnover were factors pointed out by interviewees when approaching the motives for their search fora gamified tool.

We implemented gamification to actually decrease the turnover and to make commission more attractive to employees [E2].

Improvements were also informed in the organizational climate, awards and employees' feelings of recognition by the organization (ALVES, 2015). One of the senior consultants reported a $15 \%$ to $20 \%$ increase in revenues and engagement. Related to the turnover, he pointed out a $50 \%$ decrease in one of the operations he managed. The manager of changes of a retailer with 10 thousand employees informed that the gamification platform for learning initially had $88 \%$ engagement which successively increased.

The interviewees showed to be involved by the symbolic context of the game format. It was observed learning-related sensemaking and management-engaging practices, both when talking about rules and objectives and when dealing with the company's recognition of employees' efforts. The stories used within those symbolic contexts reported by the interviewees were presented, most of them, as a sequence of events truthfully representing the activities to be carried out. Potential engagement would become perceptible as the employee was called by the game to always move ahead to the next level. From this one can infer that the games' design and aesthetics consolidate even more the experience. Related to the duration of the game, variations were observed according to the company's needs.

We can see that aligned communication has significantly favored engagement (...). Every Wednesday we have weekly highlights, free content oriented toward digital culture, agile tools, feedback, sales experiences. Those are quick and objective pills of knowledge; it has favored engagement in order to get to know the tool [E5]. 
A positive effect of engagement enabled by gamification is training. The complexity of some games offers excellent training of skills related to leadership and teamwork (ISMAIL, VAN GEES and MALONE, 2018). As to learning, the cooperative model is very much used in corporate games, where people cooperate around a common objective, working together to conquer resources and objectives (ALVES, 2015). This model mirrors the company's dedication to promoting clear communication with its employees and to stimulating teamwork and information sharing.

\section{Individual dimension}

By analyzing gamification and its whole potential for players' personal development (MATURANA and VERDEN-ZÖLLER, 2004), a dimension of individual learning can be observed. As identified in the interviews, the tool should meet players' expectations and their actual needs to ensure their involvement and, as such, to increase learning.

This is one of gamification's pillars: understanding which is people's objective that should be aligned to the company's objective. It is worth stressing that gamification does not move ahead by itself; communication strategy is required. It is not just any game, people are not playing it to pass the time [E1].

The employees' profile has to be assessed so that a persona can be built up and the target audience's extrinsic and intrinsic motivations have to be understood in addition to the type of player is going to be involved. Lack of interest and motivation is one of the reasons of bad performance of corporate employees. Therefore, behavioral researchers try to create solutions able to engage employees in their daily activities so that they achieve better results (CHOU, 2013; ROBSON, PLANGGER, KIETZMANN et al., 2015).

We involve people in a strategy before reaching a solution already ready. They start to feel themselves part of what is happening and then involvement increases unbelievably [E1].

Personas are created based on behaviors observed in the field and they have certain demographic and behavioral characteristics as much as those related to their activities. For instance, different generations have different patterns of behavior (POOLE, KEMP, PATTERSON et al., 2014). The baby boomer generation identify themselves with competition and hierarchical systems. The $\mathrm{X}$ generation, on the other hand, is pragmatic, individualistic, does not allow failure. The $\mathrm{Y}$ generation grew up with videogames and the Internet, they need immediate feedback; they have a more collaborative behavior and learn by doing (POOLE, KEMP, PATTERSON et al., 2014; VIANNA, VIANNA, MEDINA et al., 2014).

We have to know and understand people's profile, not only at work, but also outside the company; and the best way is talking to them and asking questions (...) (...). To ask questions about what they like, to understand the person's context, what they think about the company, what motivates and demotivates them, who are the most engaged and disengaged people and why [E1].

All those characteristics are essential for designing and implementing the gamification tool. One of the retailers interviewed pointed out the need of assessing employees' familiarity with the digital world in order to understand which would be the best way to make them adhere to the tool.

Initially we did a research on digital use, we asked them how much they used the Internet, and the answer was: I used it for banking, Facebook, Instagram, to call a cab. Then we found out that most of them would use it for complex operations, such as paying bills. This research's finding surprised researchers [E4].

All interviewees mentioned positive aspects identified by the HR leaders, such as an increase in team's engagement due to the clarity with which the information was presented on the gamified platform, an increase in employees' feelings of belonging and empowerment, in addition to autonomy, self-esteem and even more transparency in the relation between leaders and followers.

The exchange unit is e-commerce based on the concept of inventory. I put there several days off (...). However, (...) I don't give one day off to that person; that person buys one day off because it is available in the exchange unit. Then, through gamification, we have broken a bit the concept of hierarchy and power: "Power is mine, I am the one who does things, I reach the number of coins necessary to make an exchange; I am the one who makes this exchange" [E3]. 
A rupture of traditional management models, focused on hierarchy, could be observed. According to Vianna, Vianna, Medina et al. (2014), in large corporations it is common to notice a generalized feeling of frustration arising from lack of understanding of what it takes to ascend professionally. In this sense, gamification can worth its while once it suggests that departments define specific missions and transparent criteria for moving up in the company.

What is the Angel Friend? What did we do? If the guy is a "star", theoretically he can sponsor someone, and then this can also be gamified. What does to sponsor someone mean? I must give tips to that person, I must help him or her to be more assertive when doing a certain task, or to offer the ideal product mix for him to reach that result. Do you know those shortcuts? it is a way of a friend, a peer, someone equal to him, but he is a "G1", they have identical jobs, but different performances. So, how have I gamified? People in identical functions but with different performances can be recognized as they help their colleagues who have lower performance [E3].

As to learning, when we think gamification we are in a search for producing engaging experiences able to keep players focused on their essence to learn something that can impact positively on their performance (ALVES, 2015).

As to the phases involved during the implementation of the tool, it is worth pointing out that they differ among the retailers depending on the company's dynamics and culture, of the board of directors, of the final objective and of the consulting company contracted. The "human factor" was extremely important in the implementation and adhesion processes, consequently contributing to the success of the gamified tool. It is worth mentioning the "post-game" phase used by one of the interviewees (E4). After the end of the game the company offered its employees an environment called "bubble", also known as tasting environment. It is a POS, a fictitious cashier where employees can train the activity to be carried out. Next, the contributions of the analyses are presented so that gamification in the organizations is understood.

\section{DISCUSSION}

This research aims at contributing to the literature on gamification in organizations by associating the game to its educational and ludic nature (BROUGÈRE, 1998). The connection between game and organizational learning was explored, and a proposal has been made for the tool to be considered a strategy of organizational learning divided into two levels, which include personal and organizational development. Generally speaking, interviewees consider gamification a positive strategy for organizations performing in the retail segment, it offers personal gains to employees through learning and personal development. Additionally, they see the tool as a new way of motivating and engaging employees and teams, and as a self-awareness strategy.

Gamification has been studied mainly in the areas of education and research, psychology, computer sciences, communication and, in a lower degree, in the areas of management and businesses. Among those studies' approaches, the highlight goes to gamification's impact as an educational tool of engagement of students, cognition, learning and communication development by means of riddles in virtual environments, engagement of clients and risk management, among others.

A view of gamification is presented according to experts' perception in its implementation in organizational environment. Based on data analysis, the exitance of good results were identified for the levels of organization and individual analysis. Thus, the positive effects of gamification can be distributed into three dimensions: organization, team/group and individual. In the organizational dimension there is improvement in productivity, organization learning, innovation processes and organizational update. In the team/group dimension, improvements in the organizational climate, communication and collaborative work were observed. In the individual dimension, there was development of employees, autonomy, self-esteem and more transparency int he relation between leaders and followers. 


\section{FINAL CONSIDERATIONS}

The exploratory nature of this study and the sample have limited the generalization of the findings. However, it suggests paths for additional empirical researches able to set qualitatively a broader impact of the gamification strategies on employees and on organization. Thus, it suggests that future researches last over six months after the implementation of the tool, the period of time identified by the interviewees as enough to measure the findings. Other limitation of this research is the managerial approach, i.e., understanding gamification as a tool to improve managerial processes. Therefore, future researches should adopt a critical approach to gamification.

The main contribution of this study is to disclose the potential of the strategy when it is used together with other elements, and to demonstrate the importance of didactically separating the analysis of the two levels relevant for a successful implementation. Most of the interviewees said that the success of gamification's implementation and maintenance was due to its alignment with other resources and strategies, such as sensitizing speeches, workplace (internal Facebook), multiplicators, managers engaged, participation of business partners/HR with work in the field, endomarketing, etc. Additionally, they highlighted the importance of the fact that the gamified platform made sense to stakeholders: high administration, direct managers and the very employees. The interviewees also reported improvement in the organizational climate as a significant gain for engaging employees, in addition to interaction between managers and team.

It is worth stressing the importance of the high administration and leaders as to disseminating the incorporation of the idea by the team. To believe in the outcome eases the process, i.e., companies oriented toward employees' development that support these gamified projects, for instance, are more prone to be successful in the implementation, because credibility has its base in the corporate culture.

The support of the area of human resources and of the changes management showed to be significant when creating strategies able to reach employees more strongly (meetings, campaigns, training courses). The preparation of leaders and multipliers was also pointed out as factor of success for the gamification program in the company, mainly to identify the desires and motivations of the group and to make the necessary adjustments while the tool is used. 


\section{REFERENCES}

ALVES, F. Gamification: como criar experiências de aprendizagem engajadoras. São Paulo: DVS Editora, 2015.

ARGYRIS, C.; SCHÖN, D. What is an organization that it may learn. In: ARGYRIS, C. (Ed.). Organizational Learning: a theory perspective. Reading: Addison-Wesley, 1978. p. 8-29.

BAJDOR, P.; DRAGOLEA, L. The gamification as a tool to improve risk management in the enterprise. BAJDOR, P.; DRAGOLEA, L. (Ed.). General insights on management: a monograph. 2011. Available at: <https://www.researchgate.net/publication/227367892>. Accessed on: Oct. 27, 2020.

BELTRÃO, K. I.; BARÇANTE, L. C. Adoção de jogo de negócios sob a perspectiva de modelo de excelência da gestão em curso de MBA: análise das avaliações multicritério por pares. Cadernos EBAPE.BR, Rio de Janeiro, v. 17, n. esp., p. 656-672, 2019.

BROUGÈRE, G. Jogo e educação. Porto Alegre: Artmed editora, 1998.

BROUGÈRE, G. Lúdico e educação: novas perspectivas. Linhas Criticas, v. 8, n. 14, p. 5-20, 2002.

BURKE, B. Gamification 2020: What is the future of gamification. Gartner Research, Stamford, Nov. 05, 2012. Available at: <https://www. gartner.com/en/documents/2226015>. Accessed on: Oct. 27, 2020.

BURKE, B. Gamificar: como a gamificação motiva as pessoas a fazerem coisas extraordinárias. São Paulo: DVS Editora, 2015.

CAILLOIS, R. Os jogos e os homens: a máscara e a vertigem. Petrópolis: Editora Vozes Ltda, 2017.

CASTELLS, M. O poder da identidade (Volume II). 1999. Available at: <https://identidadesculturas.files.wordpress.com/2011/05/castellsmo-poder-da-identidade-cap-1.pdf>. Accessed on: Oct. 27, 2020.

CHOU, Y. The 8 Core Drives of Gamification (\# 1): Epic Meaning \& Calling. Yu-Kai Chou: Gamification \& Behavioral Design. 2013. Available at: <https://yukaichou.com/gamification-study/8core-drives-gamification-1-epic-meaning-calling/>. Accessed on: Oct. 27, 2020.

D’ÁVILA, C. M. Didática lúdica: saberes pedagógicos e ludicidade no contexto da educação superior. Revista Entreideias: Educação, Cultura e Sociedade, v. 3, n. 2, p. 87-100, 2014.

DEWINTER, J.; KOCUREK, C. A.; NICHOLS, R. Taylorism 2.0: Gamification, Scientific Management and the Capitalist Appropriation of Play. Journal of Gaming \& Virtual Worlds, v. 6, n. 2, p. 109-127, 2014. Available at: <https://digitalcommons.tacoma.uw.edu/ias_pub/531>. Accessed on: Oct. 27, 2020.

DOMínGUEZ, A. et al. Gamifying learning experiences: Practical implications and outcomes. Computers and Education, v. 63, p. 380-392, 2013. Available at: <https://doi.org/10.1016/j.compedu.2012.12.020>. Accessed on: Oct. 27, 2020.

FORTUNA, T. Apresentação da Coleção Classicos dos Jogos. In: CAILLOIS, R. Os jogos e os homens: a máscara e a vertigem. Petrópolis: Editora Vozes Ltda, 2017.

GARRATT, B. The learning organisation 15 years on: some personal reflections. The Learning Organization, v. 6, n. 5, p. 202-207, 1999.
GARTNER. Gartner says by 2015, more than 50 percent of organizations that manage innovation processes will gamify those processes. Gartner Research, Stamford, Apr. 02, 2011. Available at: <http://www. gartner.com/newsroom/id/1629214>. Accessed on: Oct. 27, 2020.

GÓMEZ-PABLOS, V. B.; MUÑOZ-REPISO, A. G.-V. Opinión del profesorado hacia proyectos colaborativos con Tecnologías de la Información y Comunicación: un estudio psicométrico. Educação e Pesquisa, v. 45, p. e213768, 2019.

HUIZINGA, J. Homo ludens: o jogo como elemento da cultura (Vol. 4). São Paulo: Editora Perspectiva, 1971.

ISMAIL, S.; VAN GEES, Y.; MALONE, M. S. Organizações exponenciais: por que elas são 10 vezes melhores, mais rápidas e mais baratas que a sua (e o que fazer a respeito). Rio de Janeiro: Alta Books Editora, 2018.

JOHNSON, L.; ADAMS, S.; HAYWOOD, K. The NMC horizon report: 2011- K12 edition. Austin: The New Media Consortium, 2011.

KOSTER, R. Theory of fun for game design. Sebastopol: O'Reilly Media Inc., 2013.

LUCKESI, C. C. Ludicidade e atividades lúdicas: uma abordagem a partir da experiência interna. Educação e Ludicidade, Ensaios 02; Ludicidade o que é mesmo isso? Salvador: FACED/UFBA, 2005. p. 22-60.

MAGUIRE, M.; DELAHUNT, B. Doing a Thematic Analysis: A Practical, Step-by-Step Guide for Learning and Teaching Scholars. All Ireland Journal of Higher Education, v. 9, n. 3, p. 3351-33514, 2017. Available at: <http://ojs.aishe.org/index.php/aishe-j/article/view/335>. Accessed on: Oct. 27, 2020.

MARRAS, J. P.; TOSE, M. Avaliação de desempenho humano. São Paulo: Elsevier Brasil, 2012.

MATURANA, H. R.; VERDEN-ZÖLLER, G. Amar e brincar: Fundamentos esquecidos do humano-Do patriarcado à democracia. São Paulo: Palas Athena, 2004.

MERRIAM, S. B. Qualitative research in practice: Examples for discussion and analysis. San Francisco: Jossey-Bass Inc Pub, 2002.

NOGUEIRA, R. A.; ODELIUS, C. C. Desafios da pesquisa em aprendizagem organizacional. Cadernos EBAPE.BR, Rio de Janeiro, v. 13, n.1, p. 83-102, 2015.

ODELIUS, C. C. et al. Processos de aprendizagem, competências aprendidas, funcionamento, compartilhamento e armazenagem de conhecimentos em grupos de pesquisa. Cadernos EBAPE.BR, Rio de Janeiro, v. 9, n. 1, p. 199-220, 2011.

POOLE, S. et al. Get Your Head in the Game: Using Gamification to Connect with Generation $Y$ in the Classroom. Journal for Excellence in Business Education, v. 3, n.2, p. 274-279, 2014. Available at: <http:// repository.usfca.edu/ml>. Accessed on: Oct. 27, 2020.

REVANS, R. W. The origins and growth of action learning. Lund: Studentlitteratur, 1982.

ROBSON, K. et al. Is it all a game? Understanding the principles of gamification. Business Horizons, v. 58, n. 4, p. 411-420, 2015. Available at: <https://doi.org/10.1016/j.bushor.2015.03.006>. Accessed on: Oct. 27, 2020. 
ROBSON, K. et al. Game on: Engaging customers and employees through gamification. Business Horizons, v. 59, n. 1, p. 29-36, 2016. Available at: <https://doi.org/10.1016/j.bushor.2015.08.002>. Accessed on: Oct. 27, 2020.

SANCHEZ, E.; YOUNG, S.; JOUNEAU-SION, C. Classcraft: from gamification to ludicization of classroom management. Education and Information Technologies, v. 22, n. 2, p. 497-513, 2017. Available at: <https://doi.org/10.1007/s10639-016-9489-6>. Accessed on: Oct. 27, 2020.

SANTINHO, C. C. A utilização da gamificação para engajamento de equipes: um estudo de caso sobre a aplicação de um jogo empresarial em uma instituição financeira. 77f. 2018. Dissertação (Mestrado em Administração de Empresas) - Fundação Getulio Vargas, São Paulo, 2018.

SENA, A.; COELHO, D. Gameficação: uma análise das técnicas de engajamento atualmente utilizadas. SBC-ProceedingsofSBGames, Brasília, DF, 02 nov. 2012.

SHPAKOVA, A.; DÖRFLER, V.; MACBRYDE, J. Gamifying the process of innovating. Innovation, v. 22, n. 4, p. 488-502, 2020. Available at: <https://doi.org/10.1080/14479338.2019.1642763>. Accessed on: Oct. 27, 2020.

STRAUSS, A.; CORBIN, J. Basics of qualitative research techniques. Thousand Oaks: Sage Publications, 1998.

THENG, Y.-L. et al. The Use of Videogames, Gamification, and Virtual Environments in the Self-Management of Diabetes: A Systematic
Review of Evidence. Games for Health Journal, v. 4, n. 5, p. 352361, 2015. Available at: <https://doi.org/10.1089/g4h.2014.0114>. Accessed on: Oct. 27, 2020.

VENTRICE, C. Make their day! Employee recognition that works: Proven ways to boost morale, productivity, and profits. Oakland: Berrett-Koehler Publishers, 2009.

VERSIANI, Â.; FACHIN, R. Avaliando aprendizagem em simulações empresariais. Cadernos EBAPE.BR, Rio de Janeiro, v. 5, n. esp., p. 1-13, 2007.

VIANNA, Y. et al. Gamification, INC: Como reinventar empresas a partir de games. Rio de Janeiro: MJV Press, 2014. Available at: <http://www.livrogamification.com.br>. Accessed on: Oct. 27, 2020.

WANG, C. L.; AHMED, P. K. Organisational learning: a critical review. The Learning Organization, v. 10, n. 1, p. 8-17, 2003.

WATSON, W. R.; MONG, C. J.; HARRIS, C. A. A case study of the in-class use of a video game for teaching high school history. Computers and Education, v. 56, n. 2, p. 466-474, 2011. Available at: <https://doi. org/10.1016/j.compedu.2010.09.007>. Accessed on: Oct. 27, 2020.

WERBACH, K.; HUNTER, D. For the win: How game thinking can revolutionize your business. Washington, DC: Wharton Digital Press, 2012

ZICHERMANN, G.; CUNNINGHAM, C. Gamification by design: Implementing game mechanics in web and mobile apps. Sebastopol: O’Reilly Media Inc., 2011.

Soraia Finamor Neidenbach

ORCID: https://orcid.org/0000-0003-4894-2446

Master in Business Administration from Fundação Getulio Vargas (FGV EAESP); Professional Master in Management for Competitiveness (MPGC), São Paulo- SP, Brazil. E-mail: sfinamor@hotmail.com

Vanessa Martines Cepellos

ORCID: https://orcid.org/0000-0001-6707-9751

Lecturer at Fundação Getulio Vargas (FGV EAESP); Professional Master in Management for Competitiveness (MPGC), São Paulo - SP, Brazil.

E-mail: vanessa.cepellos@fgv.br

Jussara Jéssica Pereira

ORCID: https://orcid.org/0000-0003-3202-8414

Ph.D. student at Fundação Getulio Vargas from the School of Business Administration of São Paulo (FGV EAESP); Academic Doctorate in Business Administration (CDAE), São Paulo- SP, Brazil. E-mail: jussarajpereira@gmail.com 